\title{
Developing Rural Tourism with the Participation of Related Parties in Bac Kan Province
}

\author{
Le Ngoc Nuong", Ngo Thi Huyen Trang;, Dinh Tran Ngoc Huy", Nguyen Thi Thuy Trang* \\ "TNU - University of Economics and Business Administration (TUEBA), \\ Thai Nguyen, Viet Nam. \\ Address : Thai Nguyen University, Tan Thinh Ward, Tan Thinh, Thai Nguyen City Vietnam \\ "Banking University HCMC, Ho Chi Minh City, Viet Nam - International University of Japan, Japan. \\ Address : 36 Ton That Dam street, Dist 1, Ho Chi Minh city Vietnam
}

\section{Developing Rural Tourism with The Participation of Related Parties in Bac Kan Province}

Le Ngoc Nuong, Ngo Thi Huyen Trang, Nguyen Thi Thuy Trang, Nguyen Tien Lam

TNU - University of Economics and Business Administration (TUEBA), Thai Nguyen, Viet Nam

Article Info
Volume 4 Issue 2
Page Number: 26-36
Publication Issue :
March-April-2021
Article History
Accepted : 20 March 2021
Published :28 March 2021

\begin{abstract}
Tourism development policy will pay attention to stakeholders, especially the people, who play an important role. However, in reality, when people participate in rural tourism development, they are not equipped with basic knowledge and skills in managing and serving tourists. Because the benefits between stakeholders are still not clear, the participation of people in rural tourism development is currently only passive. Active participation need to be directed from the Government and local authorities because the concept that rural tourism development is not only about creating economic benefits but also associated with conservation and preservation, together with keeping and promoting cultural historical values in rural areas.

Keywords : Tourism development, Rural Tourism, People, Bac Kan, JEL: M10, M21, Z32
\end{abstract}

\section{INTRODUCTION}

Rural tourism in Bac Kan has just been formed for more than a decade, but has brought great benefits to participating households. In general, rural tourism in

Copyright: (C) the author(s), publisher and licensee Technoscience Academy. This is an open-access article distributed under the terms of the Creative Commons Attribution Non-Commercial License, which permits unrestricted non-commercial use, distribution, and reproduction in any medium, provided the original work is properly cited 
Bac Kan has not really developed to match the potential of a locality with a long origin in agricultural production. Together with the trend of "urbanization" today, this has opened up opportunities to develop diverse forms of tourism. in which, rural tourism is a relatively new direction.

In rural tourism development, stakeholders, especially the people, play an important role. Vietnam Tourism Law 2017 clearly states that residential communities have the right to participate and enjoy legal benefits from tourism activities, and are responsible for protecting tourism resources. Accordingly, the residential community is facilitated to invest in tourism development, restore and promote different types of cultures ... This shows that the Party and State have been highly appreciating activities of developing different types of tourism, including rural tourism.

However, the reality shows that when people participate in rural tourism development, they are not equipped with basic knowledge and skills in welcoming, managing and serving tourists. In addition, the benefit distribution mechanism among stakeholders is still not really clear. Therefore, the participation of people in rural tourism development is currently only symbolic and passive.

Therefore, the article will focus on researching, analyzing in-depth, understanding the process of people's participation in rural tourism development and through the factors affecting that participation, proposing a number of recommendations and solutions for managers in policy-making to increase their participation in the coming time.

\section{LITERATURE REVIEW}

Pretty (1995) examines different types of community participation in tourism development. Accordingly, there are 5 types of community participation. These include active participation, passive participation, consultation, participation in information provision, participation in the implementation of tourism development functions.

Tosun (2006) studies the barriers in which people participating in tourism development activities. In this study, people will be affected by three groups of barriers when deciding to participate, which are operational barriers, cultural barriers and structural barriers.

Latkova et al (2011) studies the attitudes of people when participating in tourism. This study identifies factors that influence people's participation decisions. Accordingly, there are 3 groups of influencing factors: (1) People's perception of tourism, (2) The role of barriers when participating in tourism, (3) Personal benefits received from travel.

Nguyen Viet Ha (2012) undertakes research with the aim of understanding the effect of local people's perceptions on willingness to participate in volunteer tourism in Sapa, Lao Cai, Vietnam. The research has built 4 hypotheses and proved that all 4 research hypotheses are accepted through multivariate regression model under the support of SPSS 19.0 software.

Bui Thi Thu Van (2015) performed researches on people's awareness and participation in tourism development. This study used Pearson's correlation to see the relationship between consciousness and people's participation. Accordingly, after conducting the investigation and processing the data, the results obtained is that there is a positive relationship between awareness and participation. 
Nguyen Thi My Hanh (2017) conducted research on local community participation in mountainous tourism development, a typical case in Sapa, Lao Cai. Accordingly, the theory of social exchange is used to clearly see the factors affecting people's intention to participate. The results show that the perception of factors affecting both positively and negatively influences on people's participation. Besides, the new factor is the added experience when joining tourism is a new variable proven to influence the decision to participate in tourism in the future.

Kumar and Sekhar (2020) concludes that the use of technology has evolved the way that rural tourism could be conducted. Furthermore, it has opened up ways to use rural tourism as a means to solve existing socio-economic challenges in society. An and Alarcon (2020) confirmed that efforts to understand sustainable rural tourism from the customer perspective have been increased since customer loyalty is considered important for sustainability. This study is significant in that, since it evaluated the knowledge status for the first time through systematic review and applied content analysis to academic literature related to sustainability in the sector of rural tourism, it can expand and deepen the knowledge and understanding of related topics and raise awareness of a new research direction.

\section{RESEARCH METHODS}

\section{Research sample}

Based on the research object, time and objective of the study, the author conducts a survey at tourist destinations with rural tourism development conditions in Bac Kan province according to the list of suitable sites for development. Rural tourism is based on the research results of "Vietnam rural tourism development practical handbook". Sites that have been researched and proven to have rural tourism activities include: Pac Ngoi village; Coc Toc village; Nam Dai village and Bo Lu village.

For managers: For each village, the author chooses 5 managers, so the number of questionnaires is: $4 * 5=$ 20 managers.

For residents, the total number of the population in the province that practice rural tourism in Bac Kan as of the end of 2019 is 57 households. Therefore, the author will use the overall survey method to collect information on the participation of households in rural tourism development in Bac Kan province.

Analytical model: The regression model used to analyze the factors affecting the participation of people in rural tourism development has the following form:

$\mathrm{Y}=\beta_{0}+\beta_{1} X 1+\beta_{2} \mathrm{X} 2+\beta_{3} X 3+\beta_{4} X 4+\varepsilon_{i}[1]$

+ Dependent variable $(\mathrm{Y})$ : People's participation

+ Independent variables (X) include:

X1: Benefit

$\mathrm{X} 2$ : Barriers

X3: People's opinion

X4: State policy

Current situation of participation in rural tourism development in Bac Kan province

Situation of people's participation in rural tourism development in Bac Kan province

The following research results show a relative assessment of the research subjects people on the level of people's participation in activities related to rural tourism development. Accordingly, the results were implemented with 57 people and 40 
management staff participating in rural tourism development activities in the area.

- Participate in planning process

Table 1. Situation involved in the planning process 2020

\begin{tabular}{|l|l|l|l|l|}
\hline \multicolumn{2}{|c|}{ Content planning } & \multicolumn{2}{c|}{ Resident } & \multicolumn{2}{c|}{ Managers } \\
\cline { 2 - 5 } & Amount & $\begin{array}{c}\text { Ratio } \\
(\%)\end{array}$ & \multicolumn{1}{c|}{ Amount } & $\begin{array}{c}\text { Ratio } \\
\text { (\%) }\end{array}$ \\
\hline $\begin{array}{l}\text { Participate in collecting resource data on rural } \\
\text { tourism }\end{array}$ & $43 / 57$ & 75.4 & $25 / 40$ & 62.5 \\
\hline $\begin{array}{l}\text { Participate in proposing rural tourism } \\
\text { development ideas }\end{array}$ & $49 / 57$ & 86 & $31 / 40$ & 77.5 \\
\hline $\begin{array}{l}\text { Participate in setting rural tourism development } \\
\text { goals and targets }\end{array}$ & $48 / 57$ & 84.2 & $31 / 40$ & 77.5 \\
\hline Participate in building an implementation plan & $46 / 57$ & 80.7 & $31 / 40$ & 77.5 \\
\hline
\end{tabular}

(Source: Results of survey data analysis, 2020)

The analyzed results in Table 1 show that there is a difference in the assessment between the different surveyed subjects. If the people show a high level of agreement on the contents of the planning process in which they participate, the management staff, particularly the village leaders and the sociocultural staff of Communes showed lower levels of consent. Accordingly, from the point of view of local residents, they assessed that they have the highest participation in the concept of rural tourism development in the area and that they have participated in data collection. Rural tourism is considered to be the lowest level by the people. Meanwhile, from views of managers, they appreciate the role of people in participating in the stages of proposing rural tourism development ideas; so They set rural tourism development goals and targets and develop implementation plans, although the level of consent is generally not as high as that of the people as analyzed above.

\section{Participate in the process of building an organizational structure}

Table 2. Content involved in the process of building an organizational structure 2020

\begin{tabular}{|c|c|c|c|c|}
\hline \multirow{2}{*}{$\begin{array}{c}\text { Content building organizational } \\
\text { structure }\end{array}$} & \multicolumn{2}{|c|}{ Resident } & \multicolumn{2}{c|}{ Managers } \\
\cline { 2 - 5 } & Amount & $\begin{array}{c}\text { Ratio } \\
\text { (\%) }\end{array}$ & Amount & $\begin{array}{c}\text { Ratio } \\
\text { (\%) }\end{array}$ \\
\hline $\begin{array}{l}\text { Participate in human resource proposal } \\
\text { to manage rural tourism development }\end{array}$ & $23 / 57$ & 40.4 & $13 / 40$ & 32.5 \\
\hline
\end{tabular}




\begin{tabular}{|l|c|c|c|c|}
\hline $\begin{array}{l}\text { Participate in building operational } \\
\text { regulations of the organization }\end{array}$ & $21 / 57$ & 36.8 & $12 / 40$ & 30 \\
\hline $\begin{array}{l}\text { Participate in the management staff in } \\
\text { the decision-making process of rural } \\
\text { tourism development }\end{array}$ & $26 / 57$ & 45.6 & $15 / 40$ & 37.5 \\
\hline
\end{tabular}

(Source: Results of survey data analysis, 2020)

With content participating in the process of building the organizational structure, the research results show that the level of consent on the participation content of the people is not high when the opinions are not yet $50 \%$ of the respondents agreement. Accordingly, both the management staff and the people have low assessment of the organization's process of setting up operating regulations. This can be explained by the reason that the people's education level is not high, leading to important jobs that require thinking and involving many people, people are not able to participate.

Table 3. Content involved in the design process of tourism products and services 2020

\begin{tabular}{|l|l|l|l|l|}
\hline \multirow{2}{*}{ Product design content travel services } & \multicolumn{2}{|c|}{ Resident } & \multicolumn{2}{c|}{ Managers } \\
\cline { 2 - 5 } & Amount & $\begin{array}{c}\text { Ratio } \\
(\%)\end{array}$ & \multicolumn{1}{|c|}{ Amount } & $\begin{array}{c}\text { Ratio } \\
\text { (\%) }\end{array}$ \\
\hline $\begin{array}{l}\text { Visiting and learning the model of rural } \\
\text { tourism development in localities at } \\
\text { home and abroad }\end{array}$ & $27 / 57$ & 47.4 & $21 / 40$ & 52.5 \\
\hline $\begin{array}{l}\text { Participate in proposing ideas for } \\
\text { building specific rural tourism products } \\
\text { of the locality }\end{array}$ & $42 / 57$ & 73.7 & $25 / 40$ & 62.5 \\
\hline
\end{tabular}

(Source: Results of survey data analysis, 2020)

The design process of rural tourism products is shown through the contents in Table 3 . The content of visiting and learning the model of rural tourism development in localities at home and abroad has not been appreciated by both the people and the management staff because of the real development of different types of tourism. in general, and rural tourism in particular in the research areas of Bac Kan province have not been highly appreciated by the local authorities and policy makers and the funding for this activity has not been widely allocated.

\section{- Participate in the process of receiving visitors}

Table 4. Content participates in the process of receiving visitors 2020

\begin{tabular}{|c|c|c|}
\hline Content receiving visitors & Resident & Managers \\
\hline
\end{tabular}




\begin{tabular}{|l|c|c|c|c|}
\hline & Amount & $\begin{array}{c}\text { Ratio } \\
\text { (\%) }\end{array}$ & Amount & $\begin{array}{c}\text { Ratio } \\
\text { (\%) }\end{array}$ \\
\hline $\begin{array}{l}\text { Develop regulatory regulations on } \\
\text { rural access for tourists }\end{array}$ & $38 / 57$ & 66.7 & $23 / 40$ & 57.5 \\
\hline $\begin{array}{l}\text { Provide information about tours and } \\
\text { attractions for tourists }\end{array}$ & $48 / 57$ & 84.2 & $25 / 40$ & 62.5 \\
\hline $\begin{array}{l}\text { Designing tourism products specific to } \\
\text { regions }\end{array}$ & $41 / 57$ & 71.9 & $24 / 40$ & 60 \\
\hline $\begin{array}{l}\text { Create a safe and hygienic } \\
\text { accommodation environment to serve } \\
\text { tourists }\end{array}$ & $39 / 57$ & 68.4 & $24 / 40$ & 60 \\
\hline
\end{tabular}

(Source: Results of survey data analysis, 2020)

Among the contents in which people participate in rural tourism development, the visitor welcoming process is directly related and associated with the relationships between other stakeholders in the local community. This means that the best possible reception of tourists requires a close coordination between the parties, namely local authorities, tourism service providers, industry agencies and people - subjects standing at a central role in the connection. Because of that importance, both the people and the management staff appreciate and show a high agreement with this content. In particular, the stage of providing information about tours, tourist destinations for tourists and designing tourism products specific to regions was rated highest by both participants. In addition, there is more expectation on the participation of people in creating a safe and hygienic accommodation environment to serve tourists because this is an important highlight to attract the locality.

\section{Participate in tourism promotion}

Table 5. Content participating in the promotion of tourism 2020

\begin{tabular}{|c|c|c|c|c|}
\hline \multirow{2}{*}{ Content promotion of tourism } & \multicolumn{2}{|c|}{ Resident } & \multicolumn{2}{c|}{ Managers } \\
\cline { 2 - 5 } & Amount & $\begin{array}{c}\text { Ratio } \\
\text { (\%) }\end{array}$ & Amount & $\begin{array}{c}\text { Ratio } \\
\text { (\%) }\end{array}$ \\
\hline $\begin{array}{l}\text { Participate in the promotion of rural } \\
\text { tourism services through rural tourism } \\
\text { products and services }\end{array}$ & $28 / 57$ & 49.1 & $19 / 40$ & 47.5 \\
\hline $\begin{array}{l}\text { Participate in promoting rural tourism } \\
\text { services through the media (Internet, } \\
\text { newspaper, radio, ...) }\end{array}$ & $20 / 57$ & 35.1 & $13 / 40$ & 32.5 \\
\hline
\end{tabular}




\begin{tabular}{|l|l|l|l|l|l|}
\hline $\begin{array}{l}\text { Participate in promotion through } \\
\text { service quality based on visitor } \\
\text { feedback }\end{array}$ & $26 / 57$ & 45.6 & $17 / 40$ & 42.5 \\
\hline
\end{tabular}

(Source: Results of survey data analysis, 2020)

The study shows that the promotion of rural tourism, although interested by the people and government officials, is not really appreciated. Mainly, people only participate in promoting rural tourism services through rural tourism products and services associated with famous regional specialties such as
Tay people, ... or from rural places that are wellknown. The modern and more active activities such as promoting rural tourism services through the media (Internet, newspapers, radio, ...) are not really interested in people and authorities.

\section{Participate in tourism control and management}

Table 6. Content involved in the control and management of tourism 2020

\begin{tabular}{|l|c|c|c|c|}
\hline \multicolumn{1}{|c|}{$\begin{array}{c}\text { Content control and travel } \\
\text { management }\end{array}$} & Amount & $\begin{array}{c}\text { Ratio } \\
\text { (\%) }\end{array}$ & Amount & $\begin{array}{c}\text { Ratio } \\
\text { (\%) }\end{array}$ \\
\cline { 2 - 5 } & $20 / 57$ & 35.1 & $12 / 40$ & 30 \\
\hline $\begin{array}{l}\text { Gather information on the number of } \\
\text { tourists, local tourism revenue }\end{array}$ & $21 / 57$ & 36.8 & $13 / 40$ & 32.5 \\
\hline $\begin{array}{l}\text { Compare and analyze the rural } \\
\text { tourism development indicators and } \\
\text { the actual results achieved locally }\end{array}$ & $23 / 57$ & 40.4 & $15 / 40$ & 37.5 \\
\hline $\begin{array}{l}\text { Proposing solutions to attract local } \\
\text { visitors in the future }\end{array}$ & & & & \\
\hline
\end{tabular}

(Source: Results of survey data analysis, 2020)

Activities covered here including organizational structure building; tourism promotion, as well as tourism control \& management have been participated by local people, but the level of interest and appreciation are not high for both residents and managers. Table 6 shows that only the content proposing solutions to attract local visitors in the future is of much interest to the people and officials. However, the remaining issues addressing developing strategies to control and manage rural tourism in the future have not been mentioned and concerned. A stable and sustainable development of this type of tourism can help reduce poverty, improve income and living standards of the local; however, a long-term strategy is difficult to formulate.

In addition, the results also show a comparison of the level of participation in rural tourism development 
among research subjects. Accordingly, the assessment of people about their own participation is higher than that of managers. This indicates that there is a difference in the perception and assessment between the two subjects by education level, subjective perspective as well as opinions in general.

\section{Level of participation in rural tourism development} process

The participation level is shown under two aspects: passive participation and active participation. The first two levels in the table are defined by the author as passive participation whereas the remaining four levels are generalized as active participation. Accordingly, the contents of planning, designing tourism products, services and receiving visitors are aspects in which people actively take part in. However, in terms of building the organizational structure; promotion and control \& management, the local has passively merge themselves into the process and only do such things under the steering of the authorities and receive announcement from the authorities once the work has been completed.

Table 7. Level of participation in rural tourism development in Bac Kan province 2020

\begin{tabular}{|l|c|c|c|c|c|c|}
\hline \multicolumn{1}{|c|}{ Level } & Planning & $\begin{array}{c}\text { Building an } \\
\text { organizational } \\
\text { structure }\end{array}$ & $\begin{array}{c}\text { Designing } \\
\text { tourism } \\
\text { products } \\
\text { and } \\
\text { services }\end{array}$ & $\begin{array}{c}\text { Reception } \\
\text { of visitors }\end{array}$ & Promotion & $\begin{array}{c}\text { Control \& } \\
\text { Management }\end{array}$ \\
\hline $\begin{array}{l}\text { Completely under } \\
\text { the direction of the } \\
\text { authorities }\end{array}$ & 53.3 & 74.5 & 42.1 & 32.4 & 73.2 & 72.6 \\
\hline $\begin{array}{l}\text { Be notified by the } \\
\text { regulator about rural } \\
\text { tourism are } \\
\text { development } \\
\text { activities after the } \\
\text { contents } \\
\text { completed }\end{array}$ & 55.7 & 73.6 & 43.8 & 33.6 & 74.7 & 74.5 \\
\hline $\begin{array}{l}\text { Participate } \\
\text { consulting about } \\
\text { rural tourism } \\
\text { development } \\
\text { content } \\
\text { managers for }\end{array}$ & 74.2 & 72.5 & 82.4 & 74.3 & 45.3 & 35.1 \\
\hline $\begin{array}{l}\text { Participate in } \\
\text { providing } \\
\text { information to the } \\
\text { survey } \\
\text { according to the } \\
\text { survey available }\end{array}$ & 74.5 & 54.4 & 83.5 & 73.4 & 44.8 & 54.6 \\
\hline
\end{tabular}


Le Ngoc Nuong et al Gyn Int S Ref Res J, March-April-2021, 4 (2) : 26-36

\begin{tabular}{|l|c|c|c|c|c|c|}
\hline $\begin{array}{l}\text { Participate in } \\
\text { proposing rural } \\
\text { tourism } \\
\text { development } \\
\text { policies for managers }\end{array}$ & 72.4 & 40.7 & 82.7 & 75.8 & 42.1 & 56.8 \\
\hline $\begin{array}{l}\text { Contribute material } \\
\text { and human } \\
\text { resources to rural } \\
\text { tourism }\end{array}$ & 0 & 45.8 & 62.9 & 62.1 & 41.9 & 22.4 \\
\hline
\end{tabular}

(Source: Results of survey data analysis, 2020) 
Table 8. Regression analysis of factors affecting people's participation in rural tourism development

\begin{tabular}{|c|c|c|c|c|c|c|c|}
\hline \multirow{2}{*}{ Model } & \multicolumn{2}{|c|}{$\begin{array}{l}\text { Unstandardized } \\
\text { Coefficients }\end{array}$} & $\begin{array}{l}\text { Standardized } \\
\text { Coefficients }\end{array}$ & \multirow{2}{*}{$\mathbf{t}$} & \multirow{2}{*}{ Sig. } & \multicolumn{2}{|c|}{ Collinearity Statistics } \\
\hline & B & Beta & Beta & & & Tolerance & VIF \\
\hline (Constant) & 2.316 & 215 & & 10.786 & .000 & & \\
\hline LI & 400 & .031 & 481 & 12.951 & .000 & 973 & 1.028 \\
\hline $\mathrm{RC}$ & -.176 & .033 & -.199 & -5.385 & .000 & 982 & 1.019 \\
\hline QD & 120 & .032 & .142 & 3.728 & .000 & 925 & 1.082 \\
\hline CS & .106 & .031 & .129 & 3.372 & .001 & 919 & 1.088 \\
\hline
\end{tabular}

(Source: Results of survey data analysis, 2020)

\section{CONCLUSION}

The study comes to some conclusions and suggests policies to increase the participation of people in rural tourism development based on the analysis of the situation and the model of factors affecting participation of people in rural tourism development in Bac Kan province. As follows:

Increase the benefits of rural tourism

It is necessary to have initial support for newcomers to tourism, such as: investment consulting, consulting on production and business techniques, organizing training courses, to help them acquire the necessary skills and knowledge to provide the best CBT products.

Local authorities need to involve farmers in their research in order to add new value with their own "rural" resources to develop services;
Ít is necessary to clearly identify the goal of tourism in rural areas is to to develop ecotourism and cultural tourism with the mode of diversifying participants. Efficient exploitation of resources for tourism development needs to pay attention and share benefits with local communities, ensuring sustainable development.

Limit barriers in rural tourism development

Information on tourism development planning, plans and policies should be transparently publicized, so that communities in the region can actively participate. It is necessary to consider the main factors for rural tourism development, which includes community factors and building up the traditional cultural identity of each ethnic group, each locality; participation of rural communities and people, as subjects of rural tourism; promote the role of other stakeholders. 
The authorities at all levels, especially the grassroots level, need to organize forums for people to contribute their opinions on tourism development plans and tourism plans in the area. Through the participation of local communities to develop traditional industries and festivals, tourists can visit and experience with rural communities.

Travelling agencies together with local authorities should recommend to the superior authorities to remove barriers to rural tourism development such as quality of local tourism human resources, people's knowledge and experience, and people working in tourism,

\section{Raising people's awareness about rural tourism}

- Visit each household, talk and listen to people's opinion. This is a basic method to create opportunities for conversation, openness and intimacy, thereby confirming people's desire to participate in tourism, listening to their comments and assessments.

- Group discussion: Group discussions are conducted according to local units or industry groups. Group discussion is a meeting with a large number of participants, according to specified topics. Through group discussion, it is possible to see the major opinion of the people in the area on relevant issues, thereby building Overall measures to impact groups of people in the region.

- $\quad$ Organize training programs for people: Training sessions may or may not be tourism related. Topics may be related to agriculture and new rural construction incorporating tourism development. In addition, training programs can also be designed to raise people's awareness by combining educational, propaganda and economic methods.

Complete State policies to support rural tourism development

The State needs to improve tourism planning for each locality and strengthen state management to implement approved plans. For localities that already have a clear potential for rural tourism development, priority must be given to developing infrastructure, supporting facilities to attract more tourists;

To Improve mechanisms and policies to manage tourism services, open classes for local government officials to raise awareness about tourism development. Continue to improve the management mechanism, simplify administrative procedures, create an open environment to attract investment in tourism development

To build a mechanism to attract capital from the people to invest in tourism development; implement the socialization of the conservation and embellishment of monuments, landscapes, festivals, folklore activities, craft villages ... for tourism development. Perfecting tourism development mechanisms and policies to create the most favorable conditions for residential communities to participate in tourism activities.

To develop mechanisms to attract capital from the people to invest in tourism development, to socialize the conservation and embellishment of monuments, landscapes, festivals, folklore activities, and villages. profession ... for tourism development.

To step up the training of human resources for tourism enterprises, to introduce rural tourism 
development training programs to training establishments;

Strengthen market expansion and propaganda for rural tourism programs built on the basis of ensuring the relationship between exploitation and sustainable development of natural resources

\section{Acknowledgement}

Thank you editors, friends and Mr Dinh Tran Ngoc Huy (dtnhuy2010@gmail.com) to support this publication.

\section{REFERENCES}

[1]. Ministry of Culture, Sports and Tourism (2013), Practical manual for rural tourism development in Vietnam, Ha Noi.

[2]. An, W., Alarcon, S. (2020). How Can Rural Tourism Be Sustainable? A Systematic Review, Sustainability 2020, 12

[3]. Bac Kan Statistical Office(2020), Statistical Yearbook of Bac Kan in 2019.

[4]. Cengiz T. et al. (2011), "Participation of the local community in the tourism development of Imbros (Gokceada)", African Journal of Agriculture Research, 6 (16), pp. 3832-3840.

[5]. Ertuna, B. \& Kirbas, G. (2012), "Local community involvement in rural tourism development: The case of Kastamonu, Turkey", Special Issues, 10(2).

[6]. Huy, Dinh T.N., (2012), Estimating Beta of Viet Nam listed construction companies groups during the crisis, Journal of Integration and Development, 15(1).

[7]. Huy, D. T.N., Loan, B. T., and Anh, P. T. (2020). 'Impact of selected factors on stock price: a case study of Vietcombank in Vietnam', Entrepreneurship and Sustainability Issues, vol.7, no.4, pp. 2715-2730. https://doi.org/10.9770/jesi.2020.7.4(10)

[8]. Huy, D. T.N., Dat, P. M., và Anh, P. T. (2020). 'Building and econometric model of selected factors' impact on stock price: a case study', Journal of
Security and Sustainability Issues, vol.9(M), pp. 7793. https://doi.org/10.9770/jssi.2020.9.M(7)

[9]. Huy D.T.N., Nhan V.K., Bich N.T.N., Hong N.T.P., Chung N.T., Huy P.Q. (2021). 'Impacts of Internal and External Macroeconomic Factors on Firm Stock Price in an Expansion Econometric model-A Case in Vietnam Real Estate Industry', Data Science for Financial Econometrics-Studies in Computational Intelligence, vol.898, Springer. http://doi-org443.webvpn.fjmu.edu.cn/10.1007/978-3-030-48853$6 \_14$

[10]. Kumar, S., \& Sekhar. (2020). Technology and innovation: Changing concept of rural tourism - A systematic review, Open Geosciences, 12(1).

[11]. Látková, P. \& Vogt, C. A. (2012), "Residents'attitudes toward existing and future tourism development in rural communities", Journal of Travel Research, 51(1), pp. 50-67.

[12]. Nguyen Thi My Hanh (2016), Participation of local communities in mountainous tourism development: A case study in Sapa, Lao Cai, PhD Thesis, National University of Economics, Ha Noi.

[13]. Nguyen Xuan Quyet (2016), Research on community participation in rural transport infrastructure development in Dong Nai province, PhD Thesia, Vietnam Academy of Agriculture, Ha Noi.

[14]. Nguyen Dinh Tho, \& Nguyen Thi Mai Trang (2009), Scientific research in business administration, Thong ke publishing company, Ha Noi.

\section{Cite this article as :}

Le Ngoc Nuong, Ngo Thi Huyen Trang, Dinh Tran Ngoc Huy, Nguyen Thi Thuy Trang, "Developing Rural Tourism with The Participation of Related Parties in Bac Kan Province", Gyanshauryam, International Scientific Refereed Research Journal (GISRRJ), ISSN : 2582-0095, Volume 4 Issue 2, pp. 2636, March-April 2021.

doi : https://doi.org/10.32628/GISRRJ21325

URL : http://gisrrj.com/GISRRJ21325 